\title{
REVISITING MARY DALY: HER VIEWS ON THE TRINITY, MARIOLOGY AND THE FALL AS POST-CHRISTIAN MYTHS
}

\section{Hannelie Wood}

Department of Philosophy, Practical and Systematic Theology

University of South Africa

College of Human Sciences

woodjm@unisa.ac.za

\section{ABSTRACT}

According to Daly, the church doctrines on the Triune God, Christology, Mariology and the Fall are all myths, originated from, and as a result of, patriarchy. Daly deals with many topics from a woman's viewpoint such as deity, evil, Christology, morality and the church. Daly contends throughout her works that women's power has been stolen from them through the ingrained structures of patriarchy and that women have to reclaim what is theirs. Daly believes that this means the castration of patriarchal language and images that are part of the structures of a sexist world. She sees patriarchy as a world religion and believes that all religions are subjects of patriarchy - living off female energy. Without any doubt, historically women were marginalised: not only in society but also within the church. However with this said, this article will contend that Daly has succumbed to her anger and rage against the patriarchal structures that oppressed her - and other women - placing the blame squarely on God. Daly rejected God as divine omnipotent, divine immutable and divine providence and objected to the fact that God is viewed as being changeless. The wrong ideas of God's existence were a result of androcentric theological teachings and doctrines, and she turned away from the Christian faith altogether.

Key words: Mary Daly; Trinity, Christology, Mariology; the Fall; Christology; Christian

\section{UNISA}

Studia Historiae Ecclesiasticae Volume 41 | Number 1 | 2015 pp. 138-155
DOI: http://dx.doi.org/10.17159/2412-4265 /2015/v41n1a10 Print ISSN 1017-0499 | Online 2374-3689 (C) 2015. Studia Historiae Ecclesiasticae 
myths; patriarchy

\section{Introduction}

This article is an endeavour to evaluate Mary Daly's feminist understanding of the nature of the Trinity, Mariology, and the Fall as post-Christian myths and their implications for the main stream, or traditional Christian view. In her quest to study and teach, Daly encountered many obstacles, specifically within the Catholic Church, that would later shape her views on the Trinity, Mariology, and the Fall. This article is not a sociological or psychological analysis of Daly and her life situation, but a short rendering of important biographical information to understand her development as post-Christian feminist. The article will mainly concentrate on Daly's works as discussed in Wood (2012).

\section{Biographical information}

Mary Daly was born on 16 October 1928 in Schenectady, New York, and grew up as a devoted member of the Catholic Church. At the age of 25, she earned a BA degree in English at the College of St Rose in Albany, New York. Two years later, she earned a master's degree in English literature at the Catholic University of America in Washington DC. In 1954, Daly earned a PhD in religion at the School of Sacred Theology, situated at St Mary's College in Notre Dame, Indiana (Campbell 2000, 170).

Daly wanted to study Catholic theology in the United States, but when her application was rejected on account of her sex, she pursued the degree at the University of Fribourg in Switzerland (Campbell 2000, 171). During her time at the University of Fribourg, Daly obtained a degree in sacred theology in 1960, followed by a licentiate in sacred theology in 1961, a doctorate in sacred theology in 1963, and a doctorate in philosophy in 1965 (Campbell 2000, 171).

In 1966, Boston College employed Daly as an assistant professor (Daly 1975, 5). During the same year, she published her first book Natural knowledge of God in the philosophy of Jacques Maritain. With the publication of her book The church and the second sex in 1968, in which she criticised the Catholic Church, Daly was fired by the administrators at the Jesuit-run Boston College, because her employers found the book upsetting (Daly 2006, 66). The college denied her tenure, as well as promotion to that of associate professor. Students, however, held demonstrations on her behalf, and Daly was consequently awarded tenure and the college promoted her to associate professor (Daly 2006, 67). According to Daly, this experience changed her thinking profoundly and made her more radical. She saw through the 'grim grasp of patriarchy' not only at Boston College, but also at all universities, and she states: 
My concern was no longer limited to "equality" in the church or anywhere else. I did not really care about unimaginative reform but instead began dreaming new dreams of a women's revolution. (Daly 2006, 68)

When Boston College admitted women to its College of Arts and Science, Daly knew that further battles were going to take place because she was convinced that her books, speeches and feminist philosophy and ethics courses threatened the university. She also maintained her policy of teaching women and men in separate sections of those courses. Daly experienced continued harassment 'for three more decades, but had a lot of fun fighting them back' (Daly 2006, 68). Daly's promotion to full professorship in both 1975 and 1989 was denied.

After teaching for 30 years at Boston, which saw Daly involved in a series of fights and triumphs at the university, another series of events happened which Daly calls 'bizarrely comparable to the original scenario of 1969' (Daly 2006, 69). In December 1998, Daly received a call from the chair of the Theology Department who informed her that a male undergraduate who had not met the required prerequisites to register for her courses, would be registering and attending her introduction to feminist ethics classes, with or without her consent. She was also informed that the student threatened to sue Boston College on account of sexual discrimination and that he had the backing of an ultra-right law firm in Washington DC, known as the Centre for Individual Rights (Daly 2006, 69). Daly contended that she was often wrongly accused of refusing to teach men. She attempted to explain that the student, called Duane, was the leader of the Young Republicans on campus, and was used by the Centre for Individual Rights to take advantage of the "conditions of heightened right-wing backlash, including the climate of double-think and reversal', which they promoted (Daly 2006, 70). She defended her classroom policy that she had developed in 1970 for teaching men and women separately in her feminist ethic classes because:

I saw the dulling of women's participation that occurred in mixed classes. Of course, I never refused to teach a student, female or male, who expressed interest and had completed the course prerequisites. (Daly 2006, 70)

Without Daly's knowledge, Boston College agreed to a settlement during 1998, which allowed the student to register for her classes despite the fact that he lacked the required course prerequisites. Daly was convinced that Boston College was under pressure to conform to the Vatican rule that required it to affirm its 'orthodoxy and fidelity' to Catholic teachings; the university continued its pretence of championing open academic freedom (Daly 2006, 71).

Daly refused to be trapped into allowing 'an impostor' to attend her classes so she cancelled all her classes during 1999 and took a leave of absence (Daly 2006, 71). Daly agreed to attend two meetings with the administrators of Boston College to discuss her conditions of leave and during these, she realised that the situation was treacherous. During one of those meetings, Daly said that she "panicked and 
blurted out that she would rather resign than to teach under those conditions'. The administrators used this to force her to accept a retirement agreement, which she refused (Daly 2006, 73). The university announced Daly's supposed resignation and her courses were removed from the university catalogue without notice. Daly filed a lawsuit with a civil rights attorney and feminist activist who agreed to represent her in her dispute against Boston College (Daly 2006, 73). Daly was suspended in 2000 and she sued the College for the violation of her tenure rights and breach of contract. The lawsuit was settled out of court during 2001. Daly describes her experience at Boston College as:

... being disappeared from Boston College in the spring of 1999, and the atrocities leading up to this, I can say that is was a compound traumatic event. To be more precise, it involved a complex series of shocks, each of which had multiple layers that interacted with each other. I could not understand immediately all that was happening. I sense it had something in common with gang rape... What they perpetrated against me was an act of rapism. (Daly 2006, 75)

Daly felt that this 'rapism' was not only physical, but consisted of multiple levels of 'invasion, violation, degradation, destruction and horror' (Daly 2006, 75).

Daly shared some moments she experienced during her childhood, which affected her life and contributed to her philosophical quest. Some of these 'moments' describe her mystical intuitions of be-ing (Daly 1993, 23).

When Daly was four or five years of age, she discovered 'a big gleaming block of ice in the snow'. Even then, she realised that she was in touch with something awesome - something she later called 'elemental'. Daly describes the shock she experienced as something that was awoken in her, 'the knowing of an Other dimension and the experience of the first stirrings of the call of the wild' (Daly 1993, 23).

Daly's encounter with a clover blossom had a great deal to do with her becoming a radical feminist philosopher (Daly 1993, 23). She describes her encounter as follows:

My own existential encounter with a clover blossom happened when I was about fourteen years old. I was lying on the grass after a dip in the local swimming hole in Schenectady, New York. Suddenly the clover blossom spoke two words. It said: "I am." I recall being shocked and amazed...I had the impression that the clover blossom was making a statement about itSelf - not trying to show off or overwhelm me but simply making a point. I could not forget this experience...I had never heard of an intuition like this and had not words for this event. But my life was suffused with it. It guided me on paths...it was connected with my ever-growing conviction that I wanted to become a philosopher, even though I couldn't know exactly what that word meant. (Daly 2006, 46-47) 
If a clover blossom could say 'I am,' then why couldn't I? (Daly 1993, 23). Daly describes her encounter with a hedge that provided her with new questions to pursue her desire to become a philosopher (1993, 51-52). She describes her:

... brief but everlasting affair with a hedge on the campus of Saint Mary's College, at Notre Dame, Indiana. I was about twenty-three and was studying for my doctorate at the School of Sacred Theology... One morning I happened to walk past a hedge on my way to class. It spoke two words to me. These words were 'Continued existence.' I realized eventually that this was a companion intuition to the earlier one, making explicit the duration of the verb "I am," which refers to participating in Be-ing. It Announced a Now that always Is. (Daly 2006, 47)

Daly also describes her 'dream of green', which she had later in her life. While she was a student at the Catholic University of America, she was busy translating Middle English into modern English late into the night and fell asleep, Whilst she slept she dreamed of green:

Elemental, Bedazzling Green. When I woke up, I had a revelation: "Study philosophy!" (Daly 1993, 48)

She interpreted this dream as a sign that she should focus on philosophy (Daly 1993, 49). One day when she was sitting in class, she had a sudden vision of herself 'teaching theology standing at a black board' (Daly 1998, 77).

Daly places these moments carefully in their own contexts and their purpose is to depict Daly's growing 'self-consciousness' and the process by which she calls herself a radical feminist, 'a hag, and a pirate'. She presented these moments within specific temporal frameworks, which are not a representation of a linear series of events (Campbell 2000, 168-169).

Daly's experience at Fribourg became the catalyst for her decision to leave the Catholic Church in the late 1960s. After the publication of her book Beyond God the Father in 1973, in which she challenged the structure of Christianity as a patriarchal religion and an inherently sexist religion, Daly, who also referred to herself as a radical lesbian feminist, left behind all Christian symbolism and ingrained her theology into that of women's experiences (Suhonen 2000, 114-115).

In The feminist post-Christian introduction of the church and the second sex (1975), Daly claims that she would never have written The church and the second sex if it was not for the 'great carnival event', the Second Vatican Council of the Roman Catholic Church in 1965 (Daly 1975, 9). Daly attended a meeting of the Vatican II, optimistic that meaningful and lasting reforms in the Catholic Church would take place. Instead, she felt that the future looked hopeless for women in the church. She describes the Rome of Vatican II as:

... a sea of international communication - the place/time where the Catholic Church came bursting into the open confrontation with the twentieth century. It seemed to everyone, except to the strangely foreseeing "conservatives," prophets of doom who in some perverse 
way knew what was really going on, that the greatest breakthrough of nearly two thousand years was happening. (Daly 1975, 9)

According to Daly, theologians, students, journalists and lobbyists met and shared their most secret thoughts about the church and shared a sense of hope for the church, a hope that was real but ultimately misplaced. A realisation emerged that the primary force of hope should be transferred away from the church and directed to the self and others. To Daly, it would mean that we had to all stop calling ourselves part of the church (Daly 1975, 9).

One day during the Second Vatican, Daly borrowed a journalist's identity card and attended a session at St Peter's Basilica. What she saw was a multitude of cardinals and bishops whom she describes as old men in crimson dresses. There were also women present who were mostly nuns, clothed in long black dresses with their heads veiled. Daly wrote:

The contrast between the arrogant bearing and colourful attire of the "princes of the church" and the humble, self-deprecating manner and sombre clothing of the very few women was appalling. Watching the veiled nuns shuffle to the altar rail to receive Holy Communion from the hands of a priest was like observing a string of lowly ants at some bizarre picnic. Speeches were read...but the voices were all male, the senile cracking whines of the men in red...the nuns, sat docile and listened to the reading of documents in Latin, which neither they nor the readers apparently understood. (Daly 1975, 10)

Daly also noticed that the women were cautious to ask any questions or to express an opinion, but repeatedly expressed their gratitude for the privilege of being present. Although Daly states that she did not grasp the full meaning of the scene at once, the multileveled message burned its way deep into her consciousness (Daly 1975, 10).

According to Daly, it was not only her experience of the Vatican Council that made this written expression of anger and hope possible; an article by Rosemary Lauer in 1963 was another important catalyst. Lauer (1963, 365-368) moderately criticised the church's treatment of women and Daly supported Lauer in an article 'Built-in-bias' in 1965. After this publication, a publishing house contacted Daly and asked her to write The church and the second sex (Daly 1975, 10-11).

During October 1971, the Harvard Memorial Church invited Daly to preach. Daly accepted the invitation and decided to turn the sermon into an action - 'a call for a walk-out from patriarchal religion'. As the sermon moved to an end, Daly concluded:

We cannot belong to institutional religion as it exists...The women's movement is an exodus community. Its basis is not merely in the promise given to our fathers thousands of years ago. Rather its source is in the unfulfilled promise of our mothers' lives, whose history was never recorded. Its sources are in the promise of our sisters whose voices have been robbed from them, and our own promise, our latent creativity. We can affirm now our promise and our exodus as we walk into a future that will be our own future...Our time has come. We will take our own place in the sun. We will leave behind the centuries of silence and darkness. 
Let us affirm our faith in ourselves and our will to transcendence by rising and walking out together. (Daly 1993, 138)

Daly refers to this Exodus from the church as a historic 'moment of breakthrough and recalling' and a 'metaphoric event' and a manifestation of the 'courage to leave' and the 'departure from all patriarchal religions' (Daly 1993, 139).

In the next section the views of the post-Christian Daly will be discussed.

\section{Daly's Christian and post-Christian views}

Daly states that there is a perception that exists which sees women's liberation as focusing on the generation of a new consciousness without thinking or worrying about God. Daly contests that this is a fallacy because it can cut off the radical potential of the movement (Daly 1985, 28). Women have to partake in ultimate reality in order to free themselves from Christian idolatry that has been imposed on them. The new wave of feminism:

... desperately needs to be not only many-faceted, but cosmic and ultimately religious in its vision. This means reaching outward and inward toward the God beyond and beneath the gods who have stolen our identity. (Daly 1985, 29)

Daly urges women to think more creatively. This includes the breaking of, and cracking through, idolatrous thoughts such as the belief that humans are created in the image of God. This idol breaking can be done on the level of 'internalized images of male superiority' and will exorcise one from one's consciousness and from the culture one was bred from. Women, therefore, have to dethrone religious false gods as well as the ideas and symbols of God which have been imposed upon the human spirit (Daly 1985, 29).

In Beyond God the Father, Daly identifies three false deities in Christianity: the 'God of explanation', the 'God of otherworldliness' and the 'God as the judge of sin'. The 'God of explanation' is the one to whom we turn to explain, and thus to justify something which is unexplainable such as the death or suffering of a child where it is explained as the will of God. Daly states that this deity does not commit to the task of erasing social, economic and psychological suffering and injustice. Women have to be aware that 'God's plan' is a way in which men cover up their inadequacy, ignorance and evil (Daly 1985, 30). Daly describes the 'God of otherworldliness' as the 'Judge, the one who rewards and punishes after death'. Women must become liberated from this idol by rising to a deeper awareness of 'otherworldliness' as a process of creating a counter world for themselves in order to counterfeit 'this world'. Stated simply, Daly says that this idol can be dethroned when women live a full and rich life in this world (Daly 1985, 30-31). The 'God who is the judge of sin' is one who promotes self-destructive guilty feelings, especially in women. Women suffer 'mentally and physically from this deity'. For example, Daly states that women are told that birth control and abortion are wrong and that they should be submissive to 
their husband She believes that church rituals and services degrade women and force them to be verbally and symbolically passive (Daly 1985, 31).

Daly rejects the androcentric term God, and argues that a God who is construed as a fixable and definable thing is a 'deadly deception'. Daly states that she moved away from speaking about God, androgyny and homosexuality. Whereas she used to write and speak anthropologically, she moved on to write and speak 'gynomorphically'. This she does because God represents the necrophilia of patriarchy and the Goddess affirms the life-loving be-ing of women and nature (Daly 1978, xi).

What follows is Daly's use of mythology in her discussion of the symbols of the Christian faith and her views on the myth of the Triune God, Christology, Mariology and the myth of the Fall will receive special attention.

\section{The myth of the Triune God}

In Gyn/Ecology Daly (1978) describes the patriarchal society as revolving around myths of 'processions within the triune godhead'. The son proceeds from the father and the 'holy ghost' proceeds from the father and son. All creatures take part in this procession. They proceed from the eternal processing 'god' who is their 'last end', through the sacrament of baptism. Through this sacrament, they seek reconciliation with the father because they were alienated from him through the sin of Adam and Eve (Daly 1978, 38). The father is the origin who thinks 'forth' the second person, the son, the word. The son is the perfect image of the father and is co-external and consubstantial. In their total unity, they express their mutual love by the procession of a third person called the 'holy ghost' (Daly 1978, 38).

To Daly the Triune God is an act of eternal self-absorption and self-love and states that:

The "Processions of Divine Persons" is the most sensational one-act play of the centuries, the original Love Story, performed by the Supreme All Male Cast...the epitome of male bonding...It is "sublime" (and therefore disguised) erotic male homosexual mythos, the perfect all-male marriage, the ideal all-male family, the best boys' club. (Daly 1978, 38)

This mythic paradigm of the Trinity is what Daly calls the product of Christian culture and is expressive of a patriarchal society (Daly 1978, 38).

According to Daly, Christian myths did not spring out of nowhere but have parallels with chronologically antecedent androcratic myths. She states that the 'misogynist Mix-Masters stole and reversed, contorted and distorted' antecedent myths and symbols. To Daly, the Christian concept of the 'Trinity' is assimilated in the Triple Goddess in early mythology (Daly 1978, 75).

Athena, who was the Triple Goddess is also identified as Neith, the Triple Goddess of Libya, and lived in an era in which the fatherhood was not acknowledged. The pre-Hellenic Triple God is also known as Hera-Demeter-Korê. In Irish mythology, the Triple Goddess's names include Fodha, Eire, and Banbha. The Triple Moon 
Goddess, Thetis, Amphitrite and Nereis, also existed in Hellenic mythology. Daly states that there were many goddesses known as Maiden, Nymph, and Crone, or Maiden, Mother and Moon (Daly 1978, 76).

Patriarchy became the dominant social structure with the forced marriage of the Triple Goddess to a trinity of gods: Hera with Zeus, Demeter with Poseidon and Korê with Hades (Daly 1978, 76).

According to Daly's analysis of the Triple Goddess, she is the foreshadow of the Christian 'Trinity' and Christian symbols. Eurynome, whose Sumerian name was also Lahu (meaning 'exalted dove') in the Pelasgian creation myth, and who was also referred to as the 'Goddess of All Things', took on the form of a dove and laid a universal egg. Her title, Lahu, was passed on to the Yahweh as creator. To Daly, against this background, the traditional symbol of the 'holy ghost' as a dove becomes absurd (Daly 1978, 76).

Daly also describes the ritual positioning of the fingers of Catholic priests when giving blessings as symbolic of the Phrygian blessing. Priests raise their thumb, index finger and middle finger whilst the other two fingers point downwards. This is symbolic of, and represents, the 'Trinity'. But, according to Daly, this Phrygian blessing was given in the name of Myrine, also known as Ay-Mari, Marian, Marianne, Marienna, the Asian Minor Great Moon-Goddess, who was the counterpart of Neith or Athena before she was reborn from Zeus's head. Myrine, as the Mother of the Gods, of which the Christian Trinity is a distorted image, is according to Daly, the gruesome reversal in the honouring of Mary as the Mother of God (Daly 1978, 77).

Daly uses the Goddess of Trivia, equivalently used with Hecate, Artemis and Diana, to point out its relevance to the Christian myth. Hecate, also known as the Goddess of Witches, had faces that could turn in three directions. Statues of Hecate were set up at the crossings of three roads. The crossing of the three roads was a cosmic symbol because it pointed to the division of the world into three parts. Hesiod praised the Goddess Hecate as the mistress of the three realms, these being earth, heaven and sea. During the Middle Ages, people believed that the crossroads were the loci of preternatural visions and happenings. Daly, in her discussion of the term trivia, describes the crossing of the three roads, the Goddess Hecate and the definitions and meaning of the word trivia as common, ordinary, flimsy and of little worth. She points out that in a patriarchal society values that are commonplace are of little worth, but in a competitive hierarchical society, that which is scarce has intrinsically more worth. She states that the Christian 'Trinity' is seen as omnipresent through its dogma and is not associated with triviality. Daly sees this as a contradiction because androcracy makes scarcity an inherent requisite for great worth, but still finds it fitting to name the infinite, perfect, supreme 'God' as omnipresent (Daly 1978, 78).

Daly contends that the omnipresent God is not commonplace because he has no place. She argues that his omni-presence is omni-absence and that to refer to his absence as presence is false. Absence is the essence of the patriarchal god, and the infinite absence of divinity in the patriarchal God is the ultimate scarcity. Daly sees 
in this the hidden meaning of his being Omega, which she decodes as 'Ultimate Nothing' (Daly 1978, 79).

Daly claims that trivia should function as a constant reminder of the patriarchal religions' reduction of real multi-dimensional presence of the 'Nothingness', created by the fathers in their own image and likeness. Trivia should also remind women of the omnipresence of reversal. Reversal means the reversing of life-engendering energy as symbolised by the Goddess, into necrophiliac 'Nothing-loving'. Hags (women) can be free in the time/space of trivia to find their own cosmic triviality and creative power (Daly 1978, 79).

\section{Christology}

In Daly's discussion on the doctrine of Jesus, she claims that it confirms the existence of the sexist hierarchy because the Christian faith does not accept that Jesus was a limited human being. She states that if women want liberation they will have to reject Christological formulas as idolatry. As God becomes limited in women's consciousness, the more they will be able to stop thinking about Jesus as the 'second person of the Trinity' who was historically assumed to have had a human nature in a 'unique hypostatic union' (Daly 1985, 69). The uniqueness and super-eminence of Jesus will become meaningless when liberated women reject the God who became incarnated as a unique male. Daly states:

I am proposing that Christian idolatry concerning the person of Jesus is not likely to be overcome except through the revolution that is going on in women's consciousness. It will, I think, become increasingly evident that exclusively masculine symbols for the ideal of "incarnation" or for the ideal of the human search for the fulfilment will not do. As a uniquely masculine image and language for divinity loses credibility, so also the idea of a single divine incarnation in a human being of the male sex may give way in the religious consciousness to an increased awareness of the power of Being in all persons. (Daly 1985, 71)

Women cannot accept the idea of a redemptive incarnation in the unique form of a male saviour. Women also cannot accept that 'a patriarchal divinity or his son is in a position to save them from the horrors they experience in a patriarchal world. Daly identifies four methods that society and the church use to avoid insight into the conflict between feminism and Christianity and applies them specifically to the problem of Christology. These categories are universalisation, particularisation, spiritualisation and trivialisation (Daly 1985, 78-81).

Firstly, the problem of Christology was avoided through universalisation. Daly states that it is universally accepted that Jesus is not 'a woman, a black, or Chinese, etcetera' which implies that women are not the only 'outsiders'. For Daly, the problem of universalisation does not lie in the fact that Jesus was male, young and a Semite, but in the exclusive identification of Jesus with God. This implies that Jesus' divinity and his being the 'image of God' makes Jesus the 'God-man', 
something which Jesus is not (Daly 1985, 79). Daly sees having faith in Jesus as 'God-man' as inauthentic and as an idolatry (Daly 1985, 79). For Daly, the problem lies in the process where the 'particularity of Jesus' maleness' does not function in the same way as the 'particularity of his Semitic identity'. This means that priests did not exclude men from the priesthood regardless of race or age, whilst they excluded all women. The universalisation of Jesus legitimates sexual hierarchy, something women must refuse (Daly 1985, 70).

Secondly, Christological issues are avoided by particularisation, which limits oppression to a particular time, place, institution and area of activity. Particularisation is used to escape Christological issues 'by shifting the emphasis to a specific set of conditions' and the refusal to see the 'universality of the conditioning process' (Daly 1985, 79). Particularisation fails to come to terms with the sexist bias against women (Daly 1985, 80).

Thirdly, spiritualisation is used to steer away from the patriarchal implications of Christology. Daly rejects the Pauline texts 'In Christ there is no male or female' as a spiritualised example, and contends that these are not true because Jesus remains a male. For Daly, Christ is synonymous with the name 'male'. Spiritualisation also offers the fallacy of a future, a future wherein women will finally have equality, but spiritualisation detracts from the fact that women are currently still oppressed (Daly $1985,80)$.

The fourth method is trivialisation, which is accompanied by the aforementioned methods. Daly states:

It is possible to universalize, particularize, and spiritualize away the conflict between women's becoming and Christolatry precisely because female aspirations to humanity are not being taken seriously. Women who raise the problem are frequently told to turn their minds to "more serious questions". (Daly 1985, 80-81)

Daly states that cosmic energy is symbolised in the 'Tree of Life, the Sacred Tree, which is the Goddess', in order to transform her idea into the cross of Jesus Christ. The tree of life belongs to the cult of all Great Mothers and is sacred. The tree, as a symbol, represents not only fertility but also cosmic energy. In Ancient Egypt, art was depicted as the bringing forth of the Sun itself (Daly 1978, 79). To Daly, the cosmic tree is a symbol of the Christian cross as a dead wooden rack to which a dying body is fastened with nails; this becomes the torture cross of the entire world of Christianity (Daly 1978, 79). Odin, known too as 'Hanging God', 'The Dangling One', and 'Lord of the Gallows' was worshipped by the Germans. According to Neumann, Odin facilitated the conversion of Germans to Christianity because of the similarity of their hanged god to the crucified Christ (Neumann 1972, 251). The tree of life, the cross and the gallows tree were all forms of the maternal tree. Neumann analysed the tree of live as follows:

Christ, hanging from the tree of death, is the fruit of suffering and hence the pledge of the promised land, the beatitude to come; and at the same time He is the tree of life as the god 
of the grape. Like Dionysus, he is endendros, the life at work in the tree, and fulfils the mysterious twofold and contradictory nature of the three. (Neumann 1972, 252)

Daly rejects Neumann's bland, objective scholarly style and questions why he equates the fruit of the tree of death to a pledge of the Promised Land and how Christ can be the life of work in the tree. According to her, the tree is dead and He (Jesus) is on his way to this same state (Daly 1978, 80). Daly sees the tree as mysterious but not contradictory. Daly does see a contradiction in the 'Reversal Religions' reduction/reversal of the Tree of Life' to a torture cross. The cross is many things: a bed, Christ's marriage bed, a crib, a cradle, a nest, a bed of birth and the deathbed (Neumann 1972, 256). The femininity of Christ is incorporated in that of Dionysus. This is the role to which patriarchy expects women to conform, therefore the equation of a marriage bed and deathbed makes sense to Daly, which she claims to be unintended gallows humour (Daly 1978, 81).

Daly contends that the Christian myth of Christ devours the Goddess, and that the Goddess, as the Tree of Life, becomes Christ; and as the life at work in the tree, Christ becomes the sap. Taking into consideration that the tree was the body of the Goddess, Daly claims that the violence of these assimilations can be understood as the gentle Jesus who, when he offers his body to eat and his blood to drink, becomes and plays Mother Goddess. Daly both calls and identifies Jesus as a 'fetal-identified male behind the Goddess mask that is saying let me eat and drink you alive - a crude cannibalism and veiled vampirism' (Daly 1978, 81).

Daly offers her interpretation of the blood-drinking syndrome of the Christian ritual and explains her views on the origin of the chalice and the belief that the wine it contains transforms into Christ's blood. Daly states that according to Rich (1976, 99) women invented pottery making, and that the cauldron was associated with the Mother Goddess, the Priestess-Potter, the Wisewoman and Maker. When the church stole the cauldron of women-identified transforming power, it reversed it into the chalice as a symbol of the transforming power of all-male priesthood. This resulted in patriarchal powers over others in the name of a male 'god'. A priest plays at being a priestess, and hides behind her symbol as he attempts to change wine into sacred blood. Daly sees this as the Christian version of 'male menstruation'. The chalice becomes a 'cannibalistic/necrophagous' ritual and its contents, the blood of Jesus Christ, are consumed by the pseudopriestess (Daly 1978, 83).

Daly states that in order for the male god to become the Goddess, he has to be reborn. Unlike Dionysus, who was born from the thigh of Zeus, Christ did not require a paternal thigh to be born of, nor did his mother Mary need to drink a portion of his heart as Semele, Dionysus' mother had to do. She states that Christ, in the Christian myth, existed in his own incarnation as Christ and that the consubstantial Holy Ghost impregnated Mary spiritually (Daly 1978, 83). This, according to Daly, was such a spiritual affair, that Mary remained a virgin, before, during and after his death (Daly 1978, 83). 
In the 'Androcratic invasion of the gynocentric realm', the female presence is replaced by male femininity. This to Daly, is evident in the multiple rebirths of the divine Son, such as in his baptism and his resurrection. These rebirths are also present in the myths of the Goddess. Persephone had to spend three months of each year in the underworld realm of her husband Hades, who raped and abducted her. Daly sees these myths as having been male-manipulated and that they functioned to 'legitimate' the transition to patriarchal control (Daly 1978, 87).

In the Christian myth, the feminine male god replaced the 'Daughter/Self' of the Goddess. When he descended to hell, he emerged on his own without any female presence in what Daly calls the 'Monogender Male Auto-motherhood' (Daly 1978, 87).

Daly calls Jesus' ascension into heaven 'a second growing up', the re-joining with his father - himself. Like Dionysus' ascension into heaven where he sat on the right hand of Zeus, Christ, as the Christian Dionysus, has done the same thing. On the basic intentionality of the 'Word made Flesh' Daly states:

The "Word" is doublespeak that drives women M-A-D, violating cognitive boundaries, preparing the way for a phallotechnic Second Coming. It is the announcement of the ultimate Armageddon, where armies of cloned Jesus Freaks (Christian and/or nonchristian) will range themselves against Hags/Crones, attempting the Final Solution to the "problem" of Female Force. (Daly 1978, 89)

\section{Mariology}

Mary, as mother of God, is one of the Catholic Church's important doctrines and without her, their sacred history is impossible. Mary is an important figure who points towards the mystery of Christ and the church and who is a norm against which new theological conceptions have to be measured (Hauke 1995, 180).

It was De Beauvoir who influenced Daly in The church and the second sex (1968) and Daly shared her views on women not being born but becoming women. According to the evolution theory, both women are convinced that one can no longer speak of an essence of man or women, or of an unchangeable God who grounds immutable orders of things. Daly was again inspired by De Beauvoir who pointed out the contrast that exists between the ancient goddess and Mary. The goddess had power and autonomy over men, whilst Mary is portrayed as a servant of God (Hauke 1995, 182).

Not only does Daly refer to Mary as a 'domesticated goddess', she also strives to free Mary from her relationship with Christ. The Catholic dogma, according to which Mary was taken up into heaven, is symbolic of the Greek god who conferred immorality upon his mother Semite, and who, in a rage, took her to heaven (Daly 1978, 87). Mary's virginity becomes a paraphrase for female autonomy - women 
have to become independent of men and must not define themselves through their relationships with men (Hauke 1995, 184).

According to Daly, the Catholic Church offered women compensation and reflected glory by equating them to Mary. Daly sees the Marian symbol as one whose function is the perpetuation of the façade of semi-identification (by relation) of females with the Christ, and is used to deflect female outrage and to inhibit their insight and hope (Daly 1985, 32).

The symbol of Mary in Catholic doctrine is only good when it is seen in relation to Jesus. Through the doctrine of Immaculate Conception, Mary is conceived without original sin, and is placed on an unreachable pedestal setting her apart from other real women. The Catholic Church uses Mary as a symbol to reinforce sexual hierarchy because 'the Immaculate Conception occurred in anticipation of Christ's divinity' (Daly 1985, 82). What is involved here for Daly, is the negation of female evil and a rejection of patriarchy. Women need not be redeemed by men (Daly 1984, 87) and through Immaculate Conception as a metaphor, parthenogenetic powers are evoked; it represents 'the process of a women creating herself free of fathers and chains' (Daly 1984, 113-114). According to Daly, the assumption dogma, where Christ actively ascended into heaven and where Mary was taken up into heaven, reinforces patriarchalism (Hauke 1995, 186).

Daly observes that Mariology creates serious division between Protestants and Catholics, but that they are in accord with her subordinate role in 'redemption' (Daly 1985, 82). Daly states that Protestants object to a Catholic Mary who is almost equal or more important than Jesus. Protestants' objections serve the purpose of reducing women's roles in marriage to those of wife and mother (Daly 1985, 83), safely domesticated within patriarchal family boundaries (Daly 1985, 85).

Although Daly criticises the Catholic Church's dogma of Mariology, she does not want to reinstate Mariology because it belongs to the patriarchal past. Mary, as a symbol, was used, according to Daly, as a two-edged sword by its male promoters and Daly contends that the God-like status of Mary is a remnant of the ancient image of the Mother Goddess $(1985,83)$.

Daly criticises, amongst others, the views of Kaufmann and Macquarrie (quoted in Daly 1985) on the image of Mary as virgin. Daly argues that Kaufmann states that the virgin birth is one of the most unfortunate confusions in the church, and that the doctrine 'attempts to understand the theological fact that for faith, Jesus Christ is Son of God'. Daly finds Kaufmann's views on the doctrine of the virgin birth more absurd than the idea of Jesus Christ as the Son of God (Daly 1985, 84). Macquarrie perceives the doctrine of the virgin birth as purely relational and questions whether the doctrine is helpful in explaining the person of Christ and whether it enables one to see Jesus as the Incarnate Word. To Macquarrie, the virgin birth points to Jesus Christ's origin in God, something Daly contests (Daly 1985, 84). Daly argues that these theologians uphold the most non-relational aspect of Mary, her virginity, and that they tie this to the male saviour and the male God (Daly 1985, 84). 
By taking the virgin symbol out of context, women are defined on a biological level with a kind of 'inverse sexual and relational definition', and to think that Mary was a virgin 'before, during, and after' the birth of Jesus is absurd and says something about 'female autonomy in the context of sexual and parental relationships' (Daly 1985, 85).

The virgin model in Catholicism is not liberating to women; nuns are still dominated by men and are dominated and confined by the physical, psychological and social powers of patriarchy. In contrast, Protestant women have only Jesus, whereas Catholic women have the 'nun'. Protestant women have 'the minister's wife' as a more 'liberating picture'. Daly concludes that women cannot be liberated within either Catholicism or Protestantism (Daly 1985, 85).

Daly contends that the virgin birth of the Christian myth confuses people by the deceptive equation of the myth with parthenogenesis. To Daly, the Catholic Mary is not the Goddess creating parthenogenetically on her own, but is 'portrayed/ betrayed as a rape victim'. Therefore, the myth of the virgin birth is deceptive and parthenogenetic; this was not a normal impregnation (Daly 1978, 84).

The 'Rape of the Goddess' in Christian myth is 'mind/spirit rape'. When Gabriel appeared to Mary (as a terrified young girl), he announced that she had been chosen to become the mother of God; she put up no resistance. This, to Daly, is religious rape. Mary, as the victim, was impregnated with the 'Supreme Seminal Idea', who became the 'Word Made Flesh'. The role of Mary is minimal; she gives unqualified consent, bears the son, adores him, and according to Catholic theology, she was saved by him (Daly 1978, 85).

Daly describes Mary as 'catatonic, dutifully dull and derivative and drained of divinity'. Her only reward was 'perpetual paralysis in patriarchal paradise' (Daly 1978, 88). Mary is an after shadow of the Great Moon-Goddess, Marian. Mary is a remnant of 'haggard holiness' in patriarchal history, a crushed crone, the symbol of women's tamed fury (Daly 1978, 88). Mary's image of the tamed Goddess was expedient of medieval Christianity and still functions in Catholicism. Mary, as the symbol of the mother of God, was according to Daly 'a sales gimmick' and 'religious rapism' used to eliminate female presence. By demolishing the Goddess, and establishing a male divinity, Christianity also paved the way for the technological elimination of women (Daly 1978, 88).

Not only does Daly focus on the Virgin Mary but also on the Fall. Daly blames the patriarchal Christian religion for creating what she calls the 'myth of the Fall'. The section below will turn the attention to Daly's views regarding original sin.

\section{The myth of the Fall}

The narrative of Adam and Eve is often interpreted as Eve being responsible for original sin. Daly uses this narrative to point to the significant role patriarchal religion plays in the oppression of women. 
Daly sees the birth of Eve as an absurd story and blatantly silly. She views it as an excellent example of how men have treated women throughout the history of patriarchy (Daly 1985, 95). Daly questions the idea that women should be blamed for all of humanity's evil. The projection of guilt upon women is Patriarchy's Fall, and Daly calls it the primordial lie. The theology of original sin, according to Daly, reveals the Fall of religion into the role of patriarchy's prostitute, and with the aid of religion patriarchy, women have become the primordial scapegoat (Daly 1985, 47).

Daly argues that the story of the Fall was a male-dominated attempt to make sense out of the tragedy of the human condition. The great achievement of this myth was that it created sexual oppression and bestowed inferiority upon women universally (Daly 1985, 47).

The myth of the Fall is a 'prototypic case of false naming' and the foundation of the structure of phallic Christian ideology has been built upon it (Daly 1985, 47). Daly contends that the Fall of man should be called the Fall of women because, as a result of this myth, women have been blamed for all the sins of the world (Daly 1985, 48). Daly states:

The attitude of negativity on the part of the male is directed against women. This, clearly, was the prevailing psychological climate which engendered the myth and sustained its credibility. However, there is more to the problem than this. The myth has provided legitimation not only for the direction of the self-hatred of the male outward against women, but also for the direction of self-hatred inward on the part of women. (Daly 1985, 48)

Daly suggests that people should re-read the Genesis text in order for women to gain liberation. She states:

... the original myth revealed the essential defect or "sin" of patriarchal religion - its justifying of sexual caste. I am now suggesting that there were intimations in the original myth - not consciously intended - a dreaded future. That is, one could see the myth as prophetic of the real Fall that was yet on its way, dimly glimpsed. In that dreaded event, women reach for knowledge and, finding it, share it with men, so that together we can leave the delusory paradise of false consciousness and alienation. In ripping the image of the Fall from its old context we are also transvaluating it. (Daly 1985, 67)

For women to receive healing from the myth of the Fall in which they are blamed for original sin, their feelings of guilt, inferiority and self-hatred must be exorcised. Women must realise that this has created demonic-possessed power in their psyche (Daly 1985, 50). Women will become liberated once they realise that they are plagued by insecurity and feelings of guilt when they stand up to men. These feelings are 'part of the original sin syndrome of complicity in sexism' (Daly 1985, 51).

Daly names several side effects that the myth of original sin has had on women. Firstly, she refers to 'psychological paralysis' which women experience from feelings of hopelessness, guilt and anxiety over social disapproval (Daly 1985, 51). To overcome these paralyses, women need to take outward action by joining and becoming involved in, amongst others, organised religion, the media, and education 
institutions. Women should use these as platforms to make their voices known (Daly 1985, 52). The second side effect of this Daly calls 'feminine antifeminism'. Antifeminist women identify with existing power structures and feel threatened by feminists. They disapprove of, and are hostile towards feminists and antifeminists, particularly those who have achieved success in a male-dominated world. Daly calls women who behave in this way 'puppets of patriarchy'. To overcome this, Daly believes that women need to make a conscious effort to bond with each other in order to support collective liberation (Daly 1985, 52). The third side effect of the myth of original sin is 'false humility'. False humility is the internalisation of male opinions in an androcentric society. Women often do not aspire to succeed; they feel guilty and fear that they might threaten the male ego. Women need to break through this attitude of self-depreciation bestowed upon them by the myth of original sin (Daly $1985,53)$. She explains that women will have to build a new image with pride and by so doing, they will dedicate their energy to a truly revolutionary movement: the eradication of evil actions aimed at women (Daly 1985, 54). The fourth side effect is described as 'women's complicity in their own mutilation is emotional dependency'. Emotional dependency extends into intellectual life and it hinders women's free and creative thought (Daly 1985, 54). Women need to take risks in order to gain their independence; in this process they will uncover and analyse those oppressive social mechanisms that have been used against them (Daly 1985, 55).

\section{Conclusion}

This article explored Daly's biographical information to understand her development as post-Christian feminist as well as her post-Christian views on the church doctrines of the Triune God, Christology, Mariology and the Fall. It is clear that Daly encountered serious problems with the church, and we see that she was extremely angry towards the church, which she viewed as patriarchal to its core. Daly argues that Christianity did not provide a viable setting for women's liberation. She viewed women's liberation as a growing threat to patriarchal religion. In her feminist views, she offers women no possibility to accommodate Christianity. To Daly, the patriarchal god has become redundant for women, and she challenges Christianity in her uncompromising language. She challenges Christian symbols and terminologies in a deliberately antagonistic and confrontational manner and her vision for a women's movement places her in direct conflict with the church and the Christian faith at large.

\section{LIST OF REFERENCES}

Campbell, D. 2000. Be-ing is Be/Leaving. In Feminist interpretations of Mary Daly, S.L. Hoagland and M. Faye eds. Pennsylvania State University Press, pp. 164-193.

Daly, M. 1965. A built-in-bias. Commonweal, 81, pp. 509-510. 
Daly, M. 1975. The church and the second sex. Revised edition. New York: Harper \& Row.

Daly, M. 1978. Gyn/ecology: The metaethics of radical feminism. Boston: Beacon Press.

Daly, M. 1984. Pure lust: Elemental feminist philosophy. Boston: Beacon Press.

Daly, M. 1985. Beyond God the Father: Towards a philosophy of women's liberation. Boston: Beacon.

Daly, M. 1993.Outercourse: The be-dazzling voyage. London: The Women's Press.

Daly, M. 1998. Quintessence... realizing the archaic future: A radical elemental feminist manifesto. Boston: Beacon Press.

Daly, M. 2006. Amazon grace: Re-calling the courage to sin big. New York: Palgrave MacMillan.

Hauke, M. 1995. God or Goddess? Feminist theology: What is it? Where does it lead? San Francisco: Ignatius Press.

Lauer, R. 1963. Women in the church. Commonweal, 79, pp. 365-368.

Neumann, E. 1972. The Great Mother: An analysis of the Archetype. Translated from German by R. Manheim. Princeton University Press.

Rich, A. 1976. Of woman born: Motherhood as experience and institution. New York: W.W. Norton.

Suhonen, M. 2000. Toward biophilic be-ing: Mary Daly's Feminist metaethics and the question of essentialism. In Feminist interpretations of Mary Daly, S.L. Hoagland and M. Faye eds. Pennsylvania State University Press, pp. 112-131.

Wood, J.M. 2012. Patriarchy, feminism and Mary Daly: A systematic-theological enquiry into Daly's engagement with gender issues in Christian theology. Unpublished doctoral thesis. Pretoria: University of South Africa. 